\title{
ULTRASTRUCTURAL STUDY ON THE LINING EPITHELIUM OF THE ORAL ROOF OF THE CAT FISH (CLARIAS GARIEPINUS)
}

\author{
Mona A. Ali \\ Department of Anatomy and Histology, Faculty of Veterinary Medicine, Tanta University, \\ Kafr El Sheikh. \\ E-mail: mona_gado@yahoo.com
}

\begin{abstract}
An ultrastructural study was performed on the epithelium of the oral roof of the cat fish (Clarias gariepinus). The epithelium of the oral roof of cat fish was formed from multilayered epithelium of different types of cells; ordinary epithelial cells, mitochondria rich cells, alarm cells and mucous secreting cells. Granular leuckocyte, lymphocytes and phagocytes- like cells were also observed. Wide intercellular irregular spaces were found demarcated by cell boundaries and reveal the epithelial cells to possessed long processes. The apical surface of superficial epithelial cells exhibits small projections. The epithelial cells joined with the adjacent cells with desmosomes. The mitochondria rich cells contained large number of glycogen granules; few rough endoplasmic reticulum and many lysosomes of different sizes. Few tubular invaginations were also present in these cells. According to the electron density of the secretory granules, two different types of mucous cells were observed, cells contained several round secretory vesicles of different electron density and cells contained vesicles of uniform electron density. The alarm cells were large electron lucent binucleated cells. Their cytoplasm contained large elongated mitochondria arranged mainly around the nucleus. The rER and free ribosomes were also scattered allover the cytoplasm.
\end{abstract}




\section{INTRODUCTION}

Cat fish possess many qualities desired in a fish for commercial production. Cat fish are hardy, live over a wide range of temperatures, and adapted well to all commonly used culture systems.

Since cat fish are continually exposed to pathogens in pond water, it is important to minimize stressors that may predispose the fish to infectious diseases by impairing function of natural defense mechanisms (Tucker and Robinson, 1991). Skin, gills and oral mucosa secrete mucous, which serves as protection for the individual. Mucous secretion is also an important factor in disease resistance and in respiratory and osmoregulatory processes (Shephard, 1994), as well as in the natural defense against parasites and pathogens (Fletcher, 1978).

In the stratified epithelium of gills, pavement epithelial cells, mucous cells, rodlet cells, granular cells and mitochondria-rich cells (chloride cells) were identified (Vigliano, et. al. 2006). In addition, alarm cells were identified in the oral roof and gills of cat fish (Ahmed and Salma, 2004 and Mona, 2005).

To our knowledge, there are no published studies on the normal ultrastructure of the epithelium lining the oral roof of cat fish. Thus, the purpose of this study was to describe the normal ultrastructural morphology of the epithelium lining oral roof of cat fish to be used as a basis for further histopathological and aquatic toxicological studies.

\section{MATERIALS AND METHODS}

\section{Electron microscopy:}

Small samples from 3 cat fish's oral roof were used for transmission electron microscopy (TEM) examination. They were fixed in freshly prepared cold glutraldehyde $2.5 \%$ in $0.1 \mathrm{M}$ cacodylate buffer $(\mathrm{pH} 7.0$ ) 
for 24 hours at $4^{\circ} \mathrm{C}$, post fixed in $1 \%$ osmium tetroxide in 0.1 cacodylate buffer, dehydrated in ascending grades of ethanol, embedded in Epon 812. Semithin sections $(200 \mathrm{~nm})$ were obtained from the epoxy resin blocks, using ultramicrotome, stained with toluidine blue, and used to select areas for thin sections. Ultrathin sections $(90 \mathrm{~nm})$ were stained with uranyl acetate and lead citrate and observed and photographed with JEOL SX 100 transmission electron microscope (Medical Research Institute,Alexandria University). The method was adapted according to Hayat (1986).

\section{RESULT}

\section{General structure:}

Semi thin sections in the oral roof of the cat fish showed that it was lined with stratified cuboidal epithelium. This epithelium was composed of three distinct zones; the basal zone, the middle zone and the outer zone. The basal zone was formed from single layer of cuboidal or columnar cells. The middle zone was composed of polyhedral cells arranged in several layers. The outer zone was formed of cuboidal cells. Alarm cells, mucous cells and light stained cells were scattered in between the epithelial cells (Fig. 1).

\section{Electron microscopy:}

The lining epithelium of the oral roof of cat fish was composed of multilayered epithelium of different types of cells. Wide intercellular irregular spaces were found demarcated by cell boundaries and reveal the epithelial cells to possessed long processes. These spaces were wider in the basal layers than the upper ones. They were either empty or contained electron lucent or slightly electron dense materials.(Fig. 2\& 3).

The stratified epithelium of the oral roof of the cat fish formed from main four types of cells; ordinary epithelial cells, mitochondria rich cells, alarm cells and mucous secreting cells. 


\section{The epithelial cells:}

They were the most abundant type of cells, which were distributed all over the epithelial layers. There were three subtypes of epithelial cells according to their situations: the basal epithelial cells, the intermediate epithelial cells and the superficial epithelial cells.

The basal epithelial cells were polyhedral or irregular in shape with many long cytoplasmic processes; their nuclei were large with indentation of its outline with one or two clear nucleoli and granular chromatin. The cytoplasm contained few organelles as, free ribosomes and rER cisterns. In addition, oval or elongated electron dense membrane bound bodies were observed near the nucleus (Fig. 4\&5).The epithelial cells were joined with the adjacent cells with desmosomes.

The intermediate epithelial cells were polyhedral in shape and had the same complement of organelles of the basal cells with presence of numerous bundles of cyto-intermediate filaments (Fig. 6).

The superficial epithelial cells were cuboidal in shape and exhibits small projections in their free surface. The apical part of these cells was slightly more electron dense than the remaining cytoplasm. The cytoplasm was filled with many electron lucent vacuoles with different shapes; round, elongated or tubular. Adjacent epithelial cells were joined by interdigitations of the lateral cell membranes, tight junction and desmosomes. (Fig. 7\& 8).

\section{Mitochondria- rich cells:}

These cells were observed between the epithelial cells of the upper layers, they were light cells arranged in clusters 2-3 cells. They were oval in shape contained slightly electron lucent cytoplasm and euchromatic

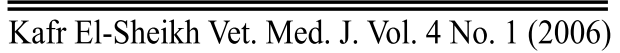


nucleus. Their cytoplasm rich in mitochondria which were large in size and had different shapes. The mitochondrial cristae were prominent. In addition, large number of glycogen granules, few rough endoplasmic reticulum and many lysosomes of different sizes were observed. Few tubular invaginations were also present in these cells. (Fig. 9\& 10).

\section{Mucous cells:}

Mucous cells were frequently observed in the uppermost layers of the epithelium. They were oval or spherical with euchromatic basally located nuclei. The supranuclear cytoplasm was filled with mucous granules. According to the electron density of the secretory granules, two different types of mucous cells were observed; cells contained several round secretory vesicles of different electron density and the others contained only electron lucent vesicles (fig.7). Mitochondria and rER were observed near the nucleus.

\section{Alarm cells:}

The alarm cells were large electron lucent binucleated cells. Their nuclei were identical euchromatic and contained electron dense nucleoli. Their cytoplasm contained large elongated mitochondria arranged mainly around the nucleus. In addition, few rER were found near the mitochondria and free ribosomes were scattered allover the cytoplasm. Small satellite cells were observed always related to the alarm cells. (Fig. 2\&11).

In addition to the before mentioned cells; phagocyte-like cells, granular leukocyte and lymphocyte were observed in the lining epithelium of the oral roof of cat fish. (Fig. 2\& 12). 


\section{DISCUSSION}

The present study revealed that the mucous membrane of the oral palate of cat fish was composed of multilayered epithelium of different types of cells. The same finding were observed in skin, gill's arch, tongue and oral cavity of different types of fish, (Ahmed and Salma, 2004; Mona and Hassan, 2005; Mona, 2005 and Vigliano, et. al. 2006). Wide intercellular irregular spaces were found demarcated cell boundaries and reveal the epithelial cells to possessed long processes, the same result was observed in stratified epithelium in all fish groups (Morgan and Tovell, 1973).

In addition, our examination revealed the presence of ordinary epithelial cells which were the most abundant cell type of the stratified epithelium of the oral roof of cat fish. These cells were detected in stratified epithelium of gills (Arellano et. al., 2004 and Vigliano, et. al. 2006) and named as pavement cells. The apical surface of the superficial epithelial cells exhibits small projections. The previous scanning electron microscopical studies in the oral roof of cat fish (Mona, 2005) showed finger-like microridges on the surface of epithelial cells. The microridges were observed on the apical surface of pavement cells of gills in other fish species (Olson, 2000b; Ahmed and Salma, 2004 and Vigliano, et. al. 2006) and in tongue (Mona and Hassan, 2005). Various functions have been proposed for the microridges, such as facilitating the adhesion of a mucous layer over the epithelial surface, allowing dynamic changes of the surface area exposed to the aquatic milieu (Olson, 2000b). On the other hand, the epithelial cells were joined with the adjacent cells with desmosomes associated with extensive network of filaments, this morphological feature most probably related with the need for providing strong cohesion between cells constantly subjected to traction forces caused by the water flow (Vigliano, et. al. 2006). 
In this investigation, Mitochondria rich cells were located on the upper layers of the epithelium of oral roof of cat fish. The mitochondria rich cells have been described in both fresh water fishes (Sargent et. al., 1978; Laurent et. al., 1985) as well as in sea fishes (Hossler, 1980). The mitochondria- rich cells were detected in skin and gills of African lung fish (Sturla, et. al.; 2001) and cat fish (Ahmed and Salma, 2004) and in the epithelium lined the pharynx of the soft- shelled turtle, (Yokosuka, et. al.; 2000). The mitochondria- rich cells were named as chloride cells in marine species exhibited the ultrastructural features typical of this cell population which is mainly involved in the active transport of ions (Laurent and Dunel, 1980; De Renzis and Bornancin, 1984; Laurent, 1984; Laurent and Perry, 1991). For this function, these cells are endowed with a large amount of mitochondria, an extensive network of tubules. In our study the mitochondria rich cells was poor in the tubular system, and this may be due to the cat fish lives in fresh water and the mitochondria- rich cells (chloride cells) were more active in fish lived in salt water. El-Habbak et. al. (1997) mentioned that the microvillus chloride cells decrease gradually in number and become almost covered by the pavement cells in advancing age in the tilapia. Total numbers and distribution of chloride cells were quantified by van der Heijden, et. al.(1999) after immunostaining of cross section of the entire larvae of tilapia with an antibody against the alpha- subunit of $\mathrm{Na} / \mathrm{K}+-\mathrm{ATPase}$ and found $80 \%$ of chloride cells in the buccal cavity five days after hatching. These cells were suggested to be involved in the uptake of $\mathrm{Na}+$ and $\mathrm{Cl}$ from fresh water for keeping ionic balance in the blood (Yokosuka, et. al.; 2000). 
According to our study, the mucous cells were frequently observed with euchromatic basally located nucleus and the supranuclear cytoplasm filled with mucous granules. According to the electron density of the secretory granules, two different types of mucous cells were observed, cells contained several round secretory vesicles of different electron density and cells contained vesicles of uniform electron density. According to Arellano, et. al. (2004), mucus cells contained vesicles of different electron density were called type A cells, and the mucus cells contained vesicles of uniform electron density were called type B cells. Different electron- dense content of mucous cell secretory vesicles has been associated with the presence of different types of mucins (Amores et. al., 1984), however, Alberts et. al., (2002) mentioned that it seems more reasonable to interpret it as a maturation process mucins. In fish species, acidic and/or neutral glycoconjugates are the main component of mucous cells (Arellano et. al., 2004). These cells secrete a mucous film over the surface. This film, joints to the stratified epithelium, protects the epithelial surface against mechanic damages and bacteria invasion, being also related to ionic absorption (Grau, 1992). Mucous is continually replenished,and when it sloughs off, it carries debris and microorganisms with it. It also contains bactericidal and antiviral factors, as well as substances that inhibit the growth of parasites on external substance (Trucker and Robinson, 1991). In addition, Domeneghini et. al. (1998), detected that the epithelium of the pharyngeal cavity and esophagus secretes neutral mucosubstance that collaborate in the enzymatic food digestion, its chime transformation and in the absorption processes.

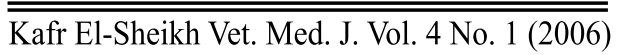


The remaining cell type identified in the epithelium of oral roof of cat fish was the alarm cells. The same cells were observed in the gills of cat fish by Ahmed and Salma, (2004). These cells are responsible for the production of alarm substance (pterin) (Harder, 1975). In addition Scott et. al. (2003), detected that the alarm substance is a chemical signal released from skin epithelial cells of juvenile rainbow trout after predator causes skin damage, and when other prey fish detect alarm substance by olfaction, they perform stereotypical predator-avoidance behaviors to decrease predation risk. Hamadani and Doving (2002), conclude that the sensory neurons with long dendrites participate in the reception of alarm phermones.

In conclusions: From the previous observations we can conclude that the oral roof of cat fish formed from four principal types of cells, ordinary epithelial cells, mitochondria- rich cells, mucous secreting cells, and alarm cells. The functions of these cells include protection, natural defense mechanisms, and production of alarm substance (pterin).

\section{FIGURES}

Fig. (1): semi- thin section showing the three distinct zones of the lining epithelium; basal zone (B), intermediate zone (I) and outermost zone (O). Alarm cells (A), light stained cells (M). (toluidine blue stain. X: 400).

Fig. (2): electron micrographs in the epithelium lining the oral roof of the cat fish showing the multilayered epithelium of different types of cells. Epithelia cell (E), mucous cells (M), alarm cells (A), satellite cells (S) and microvilli (arrow).

Fig. (3): electron micrograph showing the intercellular spaces (black arrow), lymphocyte (white arrow), epithelial cells (E) and alarm cells (A). 
Fig. (4): electron micrographs showing the epithelial cell in the basal layers contained nucleus $(\mathrm{N})$, cell process $(\mathrm{P})$, intercellular spaces contained electron lucent or slightly electron dense materials (black arrows) and electron dense membrane bound bodies (white arrow).

Fig.(5):Higher magnification of fig. 3 showing electron dense membrane bound bodies (white arrow), Rough endoplasmic reticulum (rER), desmosomes (black arrow) and the nucleus (N).

Fig. (6): electron micrograph showing the epithelial cell in the intermediate layers contained cyto-intermediate filaments (white arrow) and nucleus (N). Desmosomes (black arrow),

Fig. (7): electron micrograph showing the superficial layers of the stratified epithelium contained superficial epithelial cells (E), goblet cell type A (Ga) and goblet cell type B (Gb). Small projections (black arrow), slightly electron dense layer in the apical layer of the superficial epithelial cells (white arrow) and alarm cell (A)

Fig. (8): Higher magnification of fig. 6 showing electron lucent vacuole (v), interdigitations (arrow head) and desmosome (white arrow)

Fig. (9\&10): electron micrographs showing the mitochondria rich cells (Mrc) contained mitochondria (m), lysosomes (L), glycogen granules (white arrow), tubular invagination (black arrow) and nucleus $(\mathrm{N})$. The epithelial cells surround them $(\mathrm{E})$.

Fig.(11):Higher magnification of fig. 1 showing the alarm cells contained mitochondria (m), rER (white arrow) and nucleus (N).

Fig. (12): electron micrograph showing the phagocyte like cells in case of phagocytosis (PH) contained phagosome (black arrow). It surrounded by epithelial cells (E). 


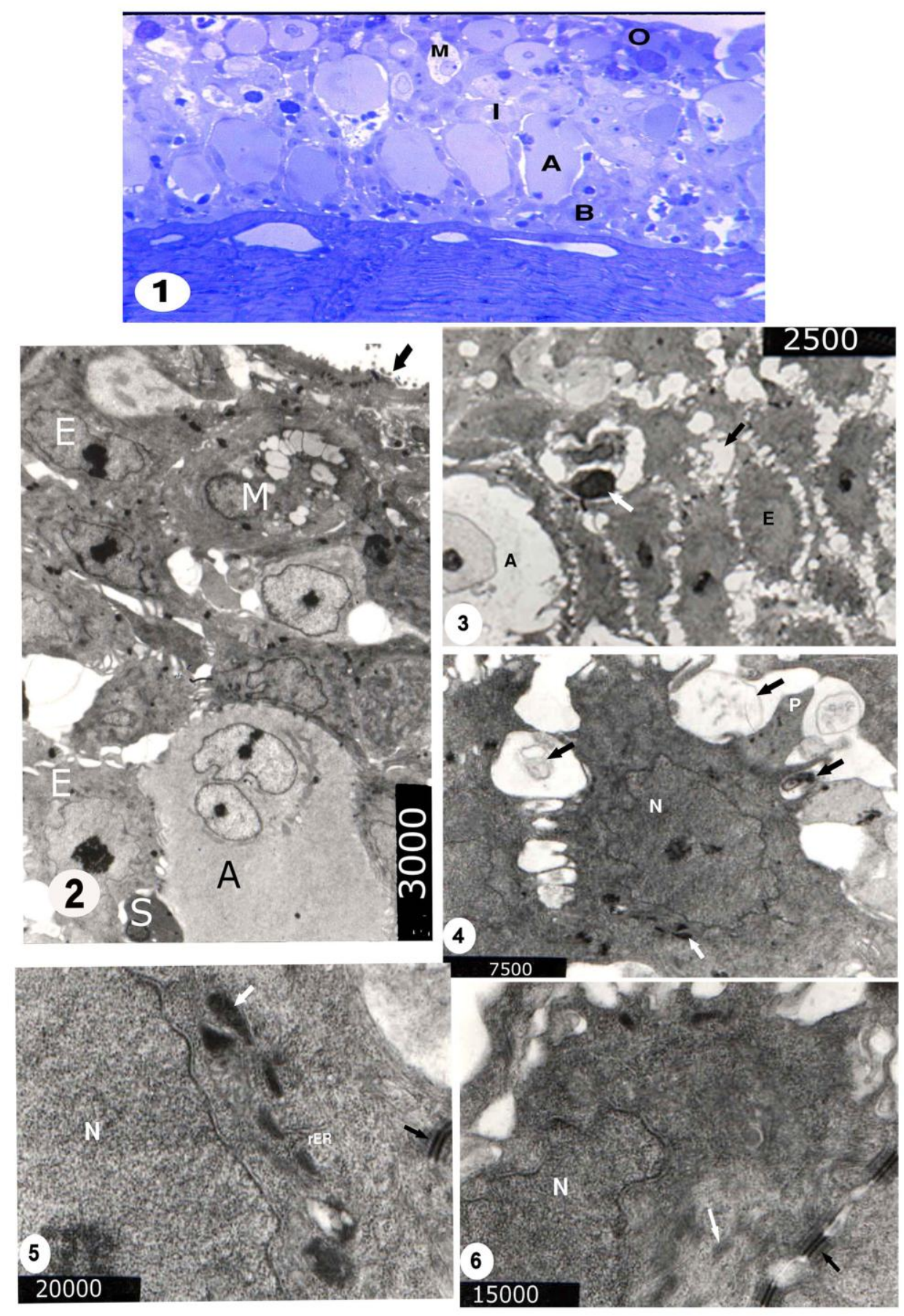

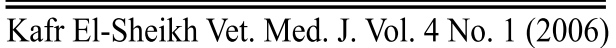



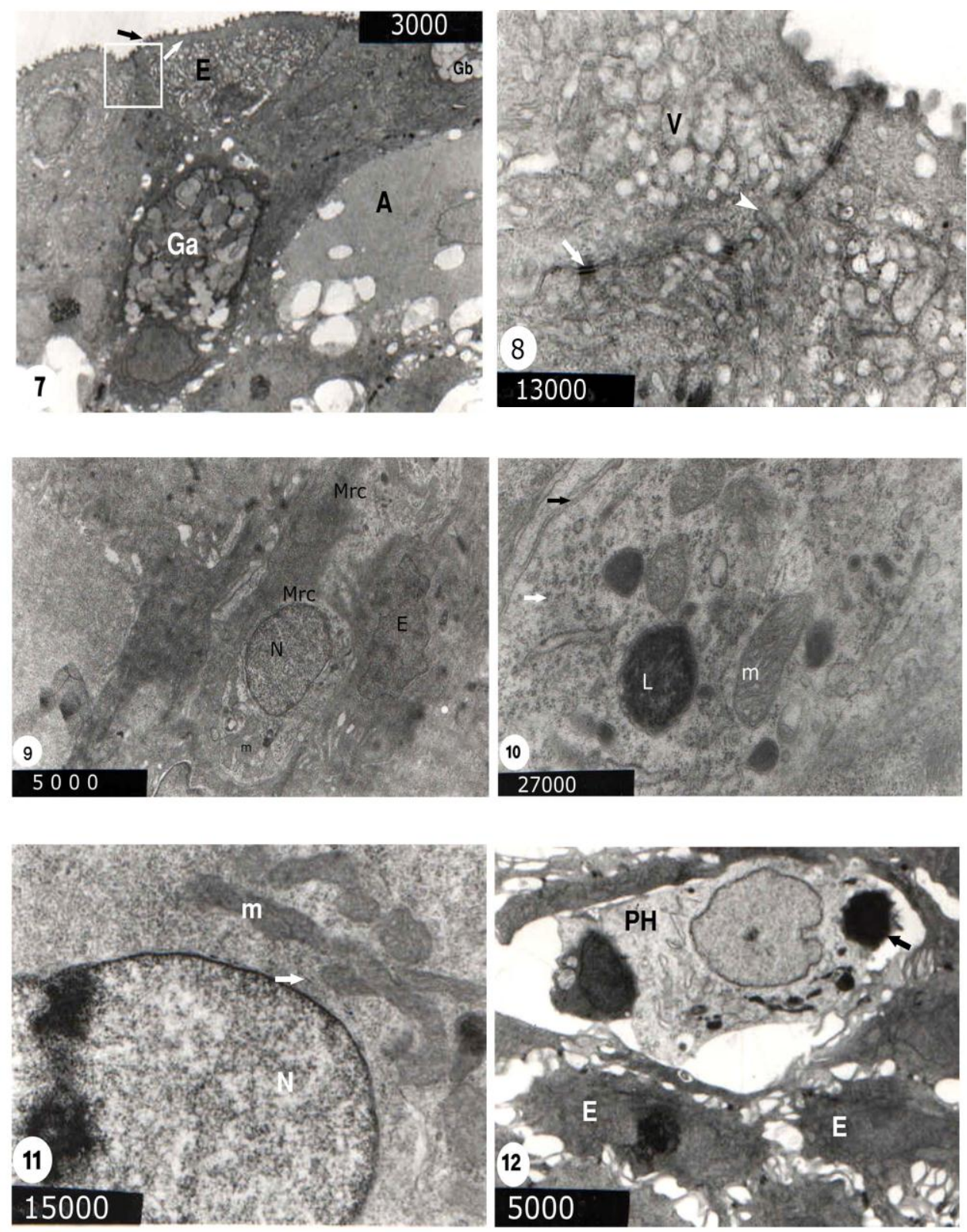

$\overline{\text { Kafr El-Sheikh Vet. Med. J. Vol. } 4 \text { No. } 1 \text { (2006) }}$ 


\section{REFERENCES}

- Ahmed E. Zayed and Salma A. Mohamed (2004): Morphological study on the gills of two species of fresh water fishes: Oreochromis niloticus and Clarias gariepinus. Ann. Anat. 186:295-304.

- Alberts B. Johnson A.; Lewis J.; Raff M.; Roberts K. and Walter P. (2002): Intracellular vesicular traffic. In: molocular Biology of the Cell, $4^{\text {th }}$ edn (Alberts B. Johnson A.; Lewis J.; Raff M.; Roberts K. and Walter P., eds.) New York: Galad Sciece Publishing, pp. 711-76.

- Amores P; Hidalgo J.; Navas P.; Sachez-Aguayo I. and Lopez Campos J. L. (1984): Cellular types in the gill arch of the teleost Cyprinus carpio (Cyprinidae, Pisces). A histochemical and ultrastructural study. Bas. Appl. Histochem. 28, 291- 307.

- Arellano J. M.; Storch V. and Sarasquete C. (2004): Ultrastruc-tural and histochemical study on gills and skin of the Sennnegal sole, Solea senegalensis. J. Appl. Ichthyol. 20. 452-460.

- De Renzis G. and Bornancin M. (1984): Ion transport and gill ATP-ases. In: Fish Physiology, Vol. XB (Soar, W. S., and D. J. Randall, Eds). New York: Academic Press, pp. 65- 104. 
- Domeneghini C.; Straini Pannelli R. and Veggetti A. (1998): Gut glycoconjugates in Sparus aurata L. (Pisces. Teleostei). A comparative histochemical study in larval and adult ages. Histol. Histopathol. 13, 359- 372.

- El-HabbakH. A., El-Gharbawy S. M. and El-Bagreesy G. A. (1997): Chloride cells of the developing gills of Oreochromis niloticus fish. Light and ultrastructure studies. Conference $21^{\text {st }}$ of the Egyptian Society of Histology and Cytology.

- Fletcher, T. C. ;( 1978): Defense mechanisms in fish. In: Biochemical and biophysical perspectives in marine biology.Vol IV. D. C. Malins and J. R. Sargent (Eds). Academic Press, London, pp.189-222.

- Grau A. (1992): Aspectos histologicos, ciclo reproductory principales procesos patologicos de Seriola dumerili, Risso 1810 (Carangiadae). Tesis doctoral, Universidad Autonoma de Barcelona, $451 \mathrm{p}$.

- Hamadani el H. and Doving K. B. (2002): The alarm reaction in crucian carp is mediated by olfactory neurons with long dendrites. Chem. Senses. 27(4):395-398.

- Harder, W. (1975): Anatomy of Fish. E Schweizer bart'sche Verlags. Buchhandlung (Naegele U. Obermiller) Stuttgart.

- Hayat, M. (1986): Basic techniques for transmission electron microscopy. Baltimore, Academic Press. $2^{\text {nd }}$ Ed. 
- Hossler F.E.(1980): The gill arch of the mullet Mugilcephalus. III. Rate of response to salinity changes. Am. J. Physiol. 238: 160- 165.

- Laurent P. (1984): Gill internal morphology. In: Fish physiology, Vol. XA (Soar, W. S. and Randall D. J., Eds). New York: Acadimic Presss, pp. 73- 183.

- Laurent, P. and Dunel S. (1980): Morphology of gill epithelia in fish. Am. J. Physiol. 238, 147- 159.

- Laurent P, Hobe H, Dunel-Erb S, (1985): The role of environmental salmonid fish. Cell Tissue Res. 240: 672692.

- Laurent P. and Perry S. F. (1991): Environmental effects on fish gill morphology. Physiol. Zool. 64, 4-25.

- Mona A. A. (2005): A microscopic study on the palatine mucosa of some River Nile fishes (Oreochromis niloticus and Clarias gariepinus). Kafr El-Sheikh Vet. Med. J. vol. 3 No. 2.

- Mona A. A and Hasan A. (2005): Morphological and histochem-ical studies on the tongue of Tilapia fish (Oreochromis niloticus). Assiut Vet. Med. J. vol. 51 No. 106. 
- Morgan, M. And Tovell P. W. A. (1973): The structure of the gill of the trout, Salmogairderi (Richardson). Z. Zellforsch. Mikrosk. Anat., 142, 147-162.

- Olson K. R. (2000b): Respiratory system. Microscopic functional anatomy. In: The Laboratory fish (Ostrander, G. K., Ed.). London: Academic Press, pp. 357- 367.

- Sargent J.R.; Pirie B. J. S.; Thomson A. J. and George J. G. (1978): Structure and function of chloride cells in the gills of Anguilla aguilla. In: Mclusky D.S. Berry A.L. (Eds) Physiology and Behavior of Marine Organisms. Oxford: Pergamon Press, pp. 123-132.

- Scott G. R.; Sloman K. A.; Rouleau C. and Wood G. M. (2003): Cadmium disrupts behavioral and physiological responses to alarm substance in juvenile rainbow trout (Oncorhynchus Mykiss). J. Exp. Biol. 206, 11: 1779-1790.

- Shepherd, K. L., (1994): Functions for fish mucus. Rev. Fish Biol. 4, 401-429.

- Sturla M.; Masini M. A.; Prato P.; Grattarola C. and Uva B. (2001): Mitochonndria- rich cells in gills and skin of an African lungfish, Protopterus annectens. Cell Tissue Res. 303(3): 351-358.

- Tucker S. and Robinson H. (1991): Channel Cat Fish Farming Hand Book. Mississippi State University. An avibook. Published by Van Nostrad Reinhold New York. 
- van der Heijden A. J.; van der Meij J. C.; Flik G. and Wenddeelaar Bonga S.E. (1999): Ultrastructure and distribution dynamics of chloride cells in tilapia larvae in fresh water and sea water. Cell Tissue Res. 297(1): 119130 .

- Vigliano, F. A., Aleman; N., Quiroga; M. I, and Nieto; J. M. (2006): Ultrastructural characterization of gills in Juveniles of the Argentinian silverside, Odontesthes bonariensis . Anat. Histol. Embryol. 35, 76- 83.

- Yokosuka H.; Ishiyama M.; Yoshie S. and Fujita T. (2000): Villiform processes in the pharynx of the softshelled turtle, Trionyx sinensis japonicus, functioning as a respiratory and presumably salt uptaking organ in the water. Arch. Histol. Cytol. 63 (2): 181-192.

دراسة التر اكيب الدقيقة للغثاء الطلائى لسقف الحلق فى سمكة القرموط

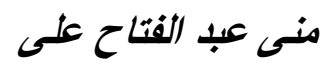

• أجرى هذا البحث على الغثاء المبطن لسقف حلق سمكة القرموط، وقد وجد أن هذا الغثاء يتكون من عديد من الطبقات مكونة من أنواع مختلفة من الخلايا مثل الخلايا الطلائية العادية و الخلايا الغنية بالميتوكوندريا و خلايا الالارم و الخلايا الدخاطية. بالإضافة الى الليكوسيت و الليفوسيت و

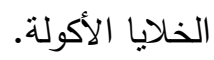


ومد فراغات واسعة غير منتظـة الثكل بين الخلايـا. يحتوى السطح الخـارجي للخلايـا الطلائية

السطحية على بروزات صغيرة، وترتبط الخلايا الطلائية مع بعضها بالديزموسوم.

تحنوى الخلايا الغنية بالميتوكوندريا على حبييات الجليكوجين و الثبكة الاندوبلازمية الخشنة و كثير

من الليسوسومات مختلقة الأحجام، كما يوجد انبعاجات أنبوبية فى السيتوبلازم.

يوجد نوعين من الخلايا المخاطية تبعا الى الكثافة الإليكترونية للحبيبات المفرزة.

تحتـوى خلايـا الألارم على نـواة كبيـرة تحتوى على 1-2 نويـة، كمـا يحتـوى السـبتوبلازم على ميتوكوندريا بقرب النواة والثبكة الاندوبلازمية الخشنة والريبوزومات الحرة. 